Article

\title{
The acquisition and use of adverbs in French as L2
}

\author{
Georges Daniel Véronique ${ }^{1, *}$ \\ 1 UMR Parole et Langage, CNRS \& Aix-Marseille Université; georges.veronique@univ-amu.fr \\ * Correspondence: georges.veronique@univ-amu.fr.
}

Abstract: The acquisition of adverbs in French as L2 (FSL) by learners with different L1s, at various levels of proficiency, has been extensively studied within various SLA projects (ESF, Interfra etc.). In the generativist tradition, it has been noted that "high category adverbs" such as those related to Mood-evaluative, Mood-epistemic and Tense are present early in FSL data. In the functionalist school, the early presence of time adverbs and scope particles in learner varieties has been analysed in relation with the informational and syntactic structures observed in these varieties and in terms of their contribution to temporal reference and other semantic domains in discourse.

On the basis of oral data obtained from guided and unguided learners of FSL from different L1 backgrounds (Spanish, Moroccan Arabic, Swedish and Japanese), the paper discusses the acquisition of adverbs in FSL in a functionalist perspective. The development of this class of words is analysed through the positions they hold in learner utterances. The paper confirms that temporal adverbs of position, scope particles and connectives precede other time adverbs. Degree quantifiers are also present in the early developmental stages of FSL. L1 transfer modifies the order of acquisition of adverbs in FSL. Notwithstanding shared commonalities, the identification of a unique development sequence for all FSL learners is a challenging task.

Keywords: time adverbs, degree quantifiers, scope particles, manner adverbs

\section{Introduction}

The purpose of this paper is to analyse some aspects of the acquisition of adverbs in French as a second language (FSL) and to describe the emergence of a class of adverbs in learner varieties of French. The paper surveys the acquisition of time and degree adverbs, which are among the first lexical and grammatical items to be observed in FSL together with connectives, and analyses the first tokens of scope particles such as aussi (also) and of -ment adverbs such as seulement (only) in learner varieties. The use of negation and of negative adverbs will not be examined in this paper but see Giuliano and Véronique (2005). The data for this paper were obtained from the Interfra (Bartning 2009) and ESF projects (Perdue 1993) on FSL and from transcribed oral data (narratives and conversation) from Japanese learners of FSL (Kerrou 2019, Klingler 1999, Renoud 2016). The acquisition of adverbs in the development of learner varieties in FSL is described in a functionalist framework (Klein 1986).

The focus of the paper is on commonalities in the acquisition and use of adverbs across FSL learners. However, variation due to L1 background or to the learning of French in naturalistic or guided settings are signalled in due course. Section 2 identifies some of the features of adverbs in French and the problems that arise in the course of the acquisition of this class of words in FSL. Section 3 outlines a functionalist perspective on development in SLA. Section 4 provides a short 
discussion of previous work on the acquisition and use of adverbs in FSL. Section 5 describes the data base for the study and the research question investigated. Section 6 presents the findings of the study and section 7 discusses some of the issues raised by these findings.

\section{Adverbs in French: definition and acquisitional issues}

According to Hengeveld (nd), "an adverb is a lexical word that may be used as a modifier of a nonnominal head". This general property seems to be the only characteristic shared by all types of adverbs, given that this set of items is fuzzy. According to Creissels (2006: 249-259), the class of adverbs comprises at least items that are near-nominals, manner adverbs and phrasal adverbs. Creissels points to the fact that a -ment adverb could be either a manner adverb related to the verb or a phrasal adverb. Hengeveld proposes a classification of adverbs according to the semantic domains covered and the scope of the items within discourse. In the formal approach developed by Cinque (1999), adverbs are the functional heads of a hierarchy of adverb phrases mainly related to Mood, Tense and Aspect.

\subsection{A classification of adverbs in French}

H. Nølke (1993:15-84) offers a brief history of previous work on French adverbs and discusses various classifications of adverbs. In this paper, I shall refer mainly to Guimier (1996) and Bonami, Godard and Kampers-Manhe (2004). For these authors, adverbs may be related to verbs and other constituents of the sentence, as integrated adverbs, or be incidental to utterances, with the property that they may be dislocated. French adverbs belong to both sets of integrated and incidental adverbs. The position and scope of adverbs vary according to their integrated or incidental status. Many classes of adverbs in French are adjuncts, occupying various key positions in the utterance, the most important and frequent one being the postverbal position. In a survey of adjuncts in French, Guimier (1993) observes that adjuncts are found principally in utterance initial, in pre- and post-verbal and final positions. Adverbs are the type of adjuncts most frequently attested in utterance initial and in pre- and post-verbal positions in French.

According to Guimier (1996) and Bonami et al. (2004 : 145), the following major semantic classes of adverbs may be identified in French: speech act adverbs (franchement 'frankly'), connectives (donc 'therefore'), attitudinal adverbs including evaluatives (heureusement 'fortunately'), modals (peut-être 'perhaps') and manner adverbs (calmement 'calmly'), 'subject oriented' adverbs (intelligemment 'intelligently'), validity adverbs or frames (légalement 'legally'), frequency adverbs (souvent 'often'), degree adverbs (beaucoup 'a lot'), duration adverbs (longtemps 'for a long time'), time adverbs (bientôt 'immediately'), negative adverbs (jamais 'never') and scope particles (aussi 'also'). Many adverbs are multifunctional; they are both time adverbs and connectives, as après (after) and alors (then) for instance.

\subsection{Learning adverbs in FSL}

Adverbs in French are made up of a wide array of lexical items which conveys a vast range of semantic and pragmatic meanings. The acquisition of this word class implies lexical parsing and 
memorization. Besides, despite the specific -ment adverbial marker, adverbs are heterogenous in meaning and form. As pointed out by Bonami et al. (2004), placement and scope of adverbs vary according to whether they are incidental or integrated to the utterance. Alignment of adverbs is constrained; for instance, "manner and degree adverbs must follow all other adverbs except time adverbs" (Bonami et al. 2004: 158). In French, the pre-verbal and post-verbal positions (between the auxiliary and the verb and after the main finite verb) are the positions where adverbs are placed most frequently (Guimier 1993: 36). Most types of integrated adverbs are inserted in post-verbal position. Thus, the acquisition of adverbs in French implies the identification and development of key positions in utterances, and of the semantic and syntactic intricacies of these lexical and grammatical items. However, because adverbs are more salient than inflection on the verb for instance, they are acquired before inflection on the verb (Ellis 2008).

\section{Stages in the acquisition of French as a second language: a functionalist perspective}

A functionalist account of SLA posits that the development of proficiency in L2 is a gradual process shared by all the learners of a specific target language (TL), bar some measure of individual variation. The acquisition of grammar in TL is shaped by semantic and pragmatic constraints of transparency, salience, diagrammatic iconicity and isomorphism (Klein 1986). According to Andersen (1984), during early SLA, learners seek a one -to-one relation between TL forms and semantic and pragmatic functions. The learners evolve from some form of iconic syntax to more arbitrary constructions.

\subsection{Towards the basic variety}

According to Klein and Perdue (1992, 1997), three major stages may be identified in the development of L2 learner varieties. At stage 1, the Nominal Utterance Organization (NUO), learner utterances are mainly lexically based and ordered following pragmatic (focus last) and semantic (Controller first) constraints. Interlanguages exhibiting such properties are known as pre-basic learner varieties (Perdue 1996). At stage 2, the Infinite Utterance Organization (IUO), utterances tend to be organised around the non-inflected verb; basic learner varieties emerge at that stage. At stage 3, the Finite Utterance Organization (FUO), verbs acquire inflection and finiteness. At NUO and IUO, utterances are shaped by pragmatic and semantic constraints, through the semantic domains of reference to entities, to time, to space, to agency and to modality which are involved in the construal of various types of texts.

In the first stages of L2 acquisition, i) discourse types are produced following a prototypical course of action; ii) utterances are organized by a small number of constructions; iii) the order of the constituents is determined by semantic and pragmatic constraints. Perdue (1996: 143) shows that at NUO, pre-basic learner utterances are highly structured and that "this structuring is the very basis for further development". In pre-basic variety (pre-BV) utterances, alignment is determined by a Topic-Focus order. Based on the same semantic and pragmatic principles as pre-BV, the basic variety $(\mathrm{BV})$ is largely independent of the target language or the first language, reflecting the "construction faculty" more than [...] (the) "copying faculty" (Klein 2009: 335) of the language acquirers (Dimroth 2018: 3). An adaptation to the properties of the target language, as well as more substantial L1 
influence, are assumed to happen only when this simple and self-contained system evolves because of communicative shortcomings and starts to develop finiteness (Klein and Perdue 1997). Thus, according to Klein and Perdue (1997), L1 transfer is rare in the very early stages of L2 acquisition. It may be observed as from the IUO stage and varies according to the linguistic domains concerned (NP, VP, PrepP, etc.) (see Ellis 2008).

\subsection{Beyond the basic variety in FSL}

Most of the naturalistic FSL learners studied in the course of the ESF project developed no further than the post-basic variety (IUO). In the wake of Klein and Perdue (1997), Bartning and Schlyter (2004) defined a more complete scale of developmental stages in FSL for Swedish L1 learners based on five major set of features: the degree of inflection of VP, the expression of Temporality (Time, Modality and Aspect), the placement of negation and the development of NP and of subordination. In Bartning and Schlyter's scale, the "initial stage" (stage 1) is similar to the pre-basic variety and the "post-initial stage" (stage 2) to the basic variety of Klein and Perdue's (1997) model. The "intermediate" stage (stage 3) is close to the post-basic variety. The more advanced stages of proficiency in FSL are identified as "advanced low" (stage 4), "advanced medium" (stage 5) and "advanced high" (stage 6). These latter stages describe L2 development beyond the three stages identified by Klein and Perdue (1997).

\section{Previous research work on the acquisition of adverbs in FSL}

Previous work on the acquisition of adverbs in FSL has been primarily devoted to time-adverbs and scope particles, mainly additive and restrictive particles. Besides the items listed in table 1, alors (then), après (after), maintenant (now), peut-être (perhaps) and vraiment (really, truly) have also been frequently analysed.

Table 1. Adverbs frequently studied in FSL data analysis

\begin{tabular}{|c|c|c|c|c|c|}
\hline & $\begin{array}{c}\text { Aussi } \\
\text { (also) }\end{array}$ & Déjà (already) & $\begin{array}{c}\text { Encore (still, } \\
\text { again) }\end{array}$ & $\begin{array}{c}\text { Toujours } \\
\text { (always) }\end{array}$ & $\begin{array}{c}\text { Seulement } \\
\text { (only) }\end{array}$ \\
\hline Spanish L1 (ESF) & + & + & + & + & + \\
\hline $\begin{array}{c}\text { Moroccan Arabic L1 } \\
\text { (ESF) }\end{array}$ & + & + & + & + & + \\
\hline $\begin{array}{c}\text { Swedish L1 } \\
\text { (Interfra) }\end{array}$ & + & + & + & + & \\
\hline
\end{tabular}

Within the generativist framework developed by Cinque (1999), Schlyter (2005) notes that "high category adverbs" such as those related to Mood-evaluative, Mood-epistemic and Tense are present early in Swedish L1 FSL data produced by low level proficiency learners of French. Schlyter (2005) points out that these adverbs, potential functional heads for adverbial phrases, are present in early 
FSL grammar, although syntactic finiteness is not yet marked on the verb. Thus, they provide an early means of marking temporality in learner varieties of FSL (see Prévost \& White 2000).

In a functionalist perspective, adverbs have been analysed in terms of scope, and in terms of their contribution to informational structure, to the semantics of learner utterances and to learners' L2 discourse. Dimroth and Watorek (2000) analysed the use of additive particle aussi in the data produced by three Spanish L1 and three Moroccan Arabic (MA) learners of FSL. They showed that in the early acquisition of FSL, scope particles such as aussi are adjacent to the item in their Domain of application (DA), and that the direction of scope is variable, with a dominant left orientation. The placement of scope particles is partly determined by the existence of contrastive topics within their DA.

Starren and Van Hout (1996) provided a first analysis of the relation between the placement of temporal adverb of duration (TAD) toujours and aspectual meaning in learner varieties. Benazzo and Giuliano (1998) and Benazzo (2005) analysing FSL data collected from Spanish L1 participants of the ESF project showed that in the course of acquisition, the scope of the particles narrows down from scope over the whole utterance to a narrow scope where the adverb is adjacent to the item within its DA. Later in the course of acquisition, after integration within the finite utterance, wide scope develops again. Sanell (2007: 121) partly confirmed Benazzo's results for aussi in pre-basic and basic varieties (stade initial and post-initial) for Swedish learners of French L2, especially in terms of adjacency. Benazzo (2005) and Sanell (2007: 128-129) have shown that additive particles are acquired before iterative particles.

Benazzo (2005) analyzed the acquisition of aussi, encore, déjà, toujours and seulement by Spanish L1 ESF learners. She observed a correlation between the acquisitional sequence of scope particles and the developmental stages of learner varieties in FSL. At the pre-basic stage, scope particles with additive and restrictive meanings bear narrow scope on NP and PP. At the basic level, scope particles carry temporal meanings such as iteration and have scope on the non-inflected verbs and its complements. At the post-basic stage, the same particles carry resultative and continuative meaning with the inflected verb within their scope. These results were confirmed by Starren (2001) for MA L1 learners of FSL in the ESF project. Versteegh (2018) summarized Benazzo's finding in Figure 1 below.

\author{
pre-Basic Variety \\ implicit reference (principle of natural order) calendrical adverbs (Monday, January 1) \\ Basic Variety \\ explicit reference \\ + anaphoric adverbs (now, yesterday) + frequency adverbs (three times) \\ + duration adverbs (one hour) \\ + boundary adverbs (begin, finally) + iterative adverbs (again)

\section{transition} \\ auxiliary verb \\ + contrastive adverbs (already, still) with scalar or compensatory meaning
}




\section{post-Basic Variety \\ finite verb \\ + contrastive adverbs (already, still) with contrastive meaning}

Figure 1. Stages in the acquisition of temporal adverbs (after Benazzo 2003) (from Versteegh 2018) This developmental sequence will be further discussed in section 7 .

Although the placement of scope particles is sensitive to the development of finiteness on the verb, finiteness on VP does not play the same role in the MA L1 learners' varieties of FSL as in the Spanish data studied by Benazzo (2005: 87-88). Scope particles are found both in the thetic and categorical constructions in MA FSL learner varieties. They occur with contrastive topics and contrastive focus. The development of scope particles in MA L1 learners of FSL seems to be determined by cognitive saliency and semantic complexity rather than by the information structure of the constructions where they occur or by the development of finiteness on VP (Véronique 2014).

Hancock and Sanell (2009) studied four French adverbs vraiment (really), peut-être (perhaps), aussi (also) and seulement (only) in the Interfra database. These adverbs were analysed in terms of the syntactic position they occupy and in terms of the semantic and pragmatic functions they fulfil within discourse. Hancock and Sanell (2009) noted that as from the 'advanced medium stage' (Bartning \& Schlyter 2004), peut-etre, vraiment and seulement are used in a native-like manner by the learners whereas aussi exhibits a non-native-like frequency. Thörle (2020) in a study of the use of aussi by German L1 advanced learners of FSL noted one non-native-like peculiarity in her data, recourse to a full pronoun bound to the NP in the scope of aussi in topic position (e.g le père lui aussi jette le repas 'the father throws away the meal too').

In a nutshell, previous studies on the acquisition of adverbs in FSL have investigated mainly the use and acquisition of time adverbs, scope particles and some -ment adverbs bearing restrictive meaning or classified as evaluatives and modals. These studies have established the interplay between the development of adverbs, the organisation of information structure and syntactic and textual development in FSL. Both Benazzo (2005) and Hancock and Sanell (2018) have proposed acquisition orders for the following adverbs aussi, encore, déjà, toujours, peut-être, seulement, and vraiment in the data they analyzed. Although development orders have been identified for specific L1 groups of learners, no common sequence has been found yet. At least one focus particle, aussi, seems to be used in a non-native like way in learner varieties, even in near-native varieties. Relevant examples from the studies discussed above will be taken up in section 6 of this paper.

\section{Research question and data base}

Adverbs are present in learner varieties from their inception. They fulfil different functions at different stages of the development of learner varieties in FSL. Drawing on previous work and exploring new data, the paper analyses the development of the word class of adverbs in FSL learner varieties by describing the role of these lexical items at three key positions in the utterance (Bernini 2014): i) between the topic component and the rest of the utterance; ii) the utterance initial position and iii) the post-verbal position. As mentioned above (section 2), these are the positions where a wide range of adverbs is found in French. The presence of adverbs in these positions in learner varieties contributes to the definition of a word class of adverbs, distinct from nouns and verbs (Bernini 2014). The paper also wishes to test the 
claims of Benazzo (2005), Versteegh (2018) and Hancock and Sanell 2018 on the course of development of adverbs in SLA.

\subsection{Data base}

The survey of the development of adverbs in FSL is based on the following sources. Data produced by unguided FSL learners of the ESF project (Arabic L1 and Spanish L1 unguided learners of French) (see table 1), and by guided Japanese L1, English L2 learners (Kerrou 2019, Klingler 1999, Renoud 2016) and from the Interfra project (Swedish L1 guided learners of French) (see table 2) will be discussed.

Table 2. Unguided learners of FSL

\begin{tabular}{|c|c|c|c|c|c|c|}
\hline & $\begin{array}{l}\text { Zahra } \\
(Z) \\
\end{array}$ & $\begin{array}{l}\text { Abdelmalek } \\
\text { (A) }\end{array}$ & $\begin{array}{l}\text { Abdessamad } \\
(\mathrm{Ad})\end{array}$ & $\begin{array}{l}\text { Alfonso } \\
(\mathrm{Al})\end{array}$ & $\begin{array}{l}\text { Berta } \\
\text { (B) }\end{array}$ & Paula (P) \\
\hline Civil Status & $\begin{array}{l}\text { Married } \\
(3 \text { children })\end{array}$ & Single & Single & Married & $\begin{array}{l}\text { Married } \\
\text { ( } 3 \text { children) }\end{array}$ & $\begin{array}{l}\text { Married } \\
\text { ( } 2 \text { children) }\end{array}$ \\
\hline Education & None & Primary & None & \begin{tabular}{|ll} 
Primary $\quad \&$ \\
secondary & $(2$ \\
years $)$ & \\
\end{tabular} & $\begin{array}{ll}\text { Primary \& } \\
\text { secondary } \\
\text { years })\end{array}$ & $\begin{array}{ll}\text { Primary } \quad \& \\
\text { secondary } \\
\text { years })\end{array}$ \\
\hline $\begin{array}{l}\text { Period of stay } \\
\text { in France } \\
\text { before } \\
\text { investigation }\end{array}$ & 13 months & 14 months & 12 months & 10 months & 1 month & 1 month \\
\hline $\begin{array}{l}\text { Courses in } \\
\text { French }\end{array}$ & $\begin{array}{ll}\text { 1h/week } & (7 \\
\text { months }) & \end{array}$ & $\begin{array}{ll}\text { 1h/week } & (7 \\
\text { months }) & \end{array}$ & $\begin{array}{ll}\text { 1h/week } & (7 \\
\text { months }) & \\
\end{array}$ & $\begin{array}{l}\text { Partial } \\
\text { attendance } \\
\text { for some } \\
\text { months } \\
\end{array}$ & None & None \\
\hline L1 & $\begin{array}{l}\text { Moroccan } \\
\text { Arabic } \\
\end{array}$ & $\begin{array}{l}\text { Moroccan } \\
\text { Arabic }\end{array}$ & $\begin{array}{l}\text { Moroccan } \\
\text { Arabic }\end{array}$ & Spanish & Spanish & Spanish \\
\hline Occupation & Textile & Fisherman & Fisherman & $\begin{array}{l}\text { Industry, } \\
\text { Hotel } \\
\text { cleaning } \\
\end{array}$ & $\begin{array}{l}\text { Kitchen } \\
\text { assistant }\end{array}$ & $\begin{array}{l}\text { Political } \\
\text { refugee }\end{array}$ \\
\hline
\end{tabular}


Table 3. Guided learners of FSL

\begin{tabular}{|c|c|c|c|c|}
\hline Informants & L1 & $\begin{array}{c}\text { Other } \\
\text { languages }\end{array}$ & $\begin{array}{c}\text { Years of study } \\
\text { of FSL }\end{array}$ & $\begin{array}{c}\text { Level of } \\
\text { proficiency } \\
\text { according to } \\
\text { Bartning and } \\
\text { Schlyter } \\
\text { (2004) }\end{array}$ \\
\hline Pelle & Swedish & English & 0 & Post-Initial \\
\hline Emelie & Swedish & English & 0 & Intermediate \\
\hline Oskar & Swedish & English & 3,5 & Intermediate \\
\hline Christina & Swedish & English & 4,5 to 6 & $\begin{array}{c}\text { Advanced } \\
\text { low }\end{array}$ \\
\hline Yvonne & Swedish & English & 4,5 to 6 & $\begin{array}{c}\text { Advanced } \\
\text { low }\end{array}$ \\
\hline Mona & Swedish & English & $7-8$ & $\begin{array}{c}\text { Advanced } \\
\text { low }\end{array}$ \\
\hline Ka & Japanese & English & 2 & Intermediate \\
\hline Mune & Japanese & English & 2 & Intermediate \\
\hline Ai & Japanese & English & 2 & Intermediate \\
\hline Ami & Japanese & English & 8 & Advanced \\
low
\end{tabular}

\section{Adverbs in FSL: results of data analysis}

In the first place, the role of degree, time, additive and restrictive adverbs at various stages of development will be surveyed. Then, some of the time adverbs and scalar adverbs will also be discussed under their guise of scope particles (König 1991), together with seulement (always). Finally, most frequent -ment adverbs will be analysed. Only significant examples shall be quoted; unless information is provided to the contrary; the uses of adverbs described below are shared by all the learners at the same stage of acquisition. Examples from guided and unguided learners of French will be provided (see Tables 2 and 3). The orthographies used for coding oral data in the various data bases explored have been maintained in the examples quoted below.

\subsection{Time Adverbs and the expression of temporality}


In this sub-section, time, frequency and duration adverbs (see 2 above) will be grouped under the label of time adverbs. The category includes Temporal adverbs of position (TAP), Temporal adverbs of duration (TAD) such as toujours (always), temporal adverbs of frequency (TAQ) such as souvent (often), and temporal adverbs of contrast (TAC) such as déjà (already).

Temporal adverbs of position (TAP) as hier (yesterday), après (after), alors (and then), ensuite (afterwards), maintenant (now) etc. are attested from the early stages in learner varieties of FSL. At the pre-basic (NUO) and basic varieties (FUO), TAP are used to express Topic time (TT) - the time of reference - or the time of the situation depicted (Tsit) (Klein 1994). Besides marking deixis and temporal anaphoric linkage, some of these adverbs contribute to maintain textual coherence (Starren 2001: 31-39; Hancock 2014) (see examples below). Some of the TAP are deictic as hier, while others, as in 1 to 5 , are anaphoric.

1. I(nvestigator). Tu me racontes comment t'es arrivé en France [ ...]? (Can you tell me how you arrived in France)

Z(ahra). avant /e/ mon mari /travaj/ pas (before my husband (does) not work) (2.1)1.

2. (Zahra describes the classes she attends)

Z. moi /iparle/ comme la cassette (= I speak / repeat after (?) the cassette)

I. oui (yes)

3. Z. /e/ après /e/ la dame tous tous la dame /iparle/ pour le livre (= and then everyone repeats what's in the book) (1.2).

4. Mune. Et le garçon et le chien /Zu/ autour de la maison puis ils /võ/ à source source glacée (And the boy and the dog play around the house then they go to the cold spring)

5. Mune. Le chien /patinaz/ sur glace avec un chaussure à patinager et ensuite le garçon /tent/ de patinager (the dog skates on the ice with skating shoes and then tries to skate)

In examples 1 to 5, TAPs provide temporal reference for the events depicted and act as inter-clausal connectives.

Temporal adverbs of duration (TAD) such as toujours (always), temporal adverbs of frequency (TAQ) such as souvent (often) and temporal adverbs of contrast (TAC) such as déjà (already) are also used early in FSL acquisition.

In early learner varieties, toujours (always) as a TAD specifies various aspectual values. In 6, toujours in initial position extends its scope over l'ardoise le premier which is within its domain of application (DA), to express habituality,

${ }^{1}$ In the course of the ESF project, data were collected from each informant on a monthly basis. 3 cycles of 9 encounters were organised. The data collecting period lasted 3 years in toto. All the tasks were repeated 3 times at ca. one year interval. Learner utterances analysed in the paper indicate the cycle and encounter where they occurred (e.g. Cycle 1, encounter 1); see Giacomi, Stoffel, Véronique eds. (2000). 
6. Z. toujours toujours l'ardoise (always always slate)

I. oui d'accord? chaque fois? (yes OK? Each time?)

Z. non toujours l'ardoise le premier (...)/e/ après le livre (no always slate first (...) and after the book)

(1.2).

In 7 and 8 , toujours is in key position 1 between the topic moi and new information /telefone/ papa. The aspectual meaning marked by toujours is iteration because of the lexical meaning of /telefone/ which depicts an activity,

7. A. deux mois moi toujours /telefone/ papa (two months, me always phone dad) (2.4).

With the same type of placement, in 8 toujours expresses continuity because of the non-telic value of mal de tête:

8. Z. un mois moi toujours mal la tête (one month me always head ache) (1.8).

As a TAQ, encore placed in utterance initial position marks continuity of TT in early FSL grammar as in 9:

9. Z. encore Rachid mal le ventre (always Rachid belly ache) (2:4)

In utterance final position associated to the focus with scope to the left, TAQ encore (still, again) relates the TSit of the event to the preceding TSit as in 10,

10. Z. /i parti/ à l'école encore (he goes to school again) (3: 2).

11. I. les deux (jambes)? (and both your legs?)

Z. oui ++ quand euh /maree//li//ma/ quand toujours euh /dor/ comme ça +/se/ bien le matin /se/ bien et après-midi encore quand euh le vent /fi/ chaud + aussi + /li/ malade (1.7).

(yes ++ when walk // when always sleep like this + it's OK in the morning it's OK and this afternoon again when the wind is warm + again (s)he is ill).

As illustrated in 11, various scalar time adverbs are mustered in Zahra's basic learner variety to convey the iterative relation between the prevailing heat, sleep and her state of health. Toujours and encore refer to the time sequence of events /dor/ (sleep) and /fil chaud (it's hot) while aussi whose scope bears on /li/ malade hinges this clause to the other utterances.

In the Swedish Interfra data (Sanell 2007: 155), encore is present as from the intermediate stage as in 12 ,

12. I. oui oui tu suis la télévision française? (yes yes do you follow on the French TV),

$\mathrm{E}$ (melie). Oui parfois bien sûr mais c'est encore un peu plus difficile (yes sometimes obviously but it is still difficult) (Sanell 2007: 155). 
Encore conveys first a continuative value and at more advanced stages, encore conveys iterative meaning. In 12 , encore regularly associated to the degree adverb peu (little) is integrated in post-verbal position in a thetic construction.

In 13, encore carries iterative meaning.

13. $\mathrm{M}$ (ona). Ils ont perdu ma valise encore une fois et il a fallu attendre trois jours encore (they have lost my suitcase once again and I had to wait for three days further) (Sanell 2007: 162).

In the Interfra data, TAC déjà is present as from the intermediate stage,

14. $\mathrm{O}($ skar) oui parce que vous / nous avons déjà regardé un peu (...) film (yes because we have already viewed a little (of) the film) (Sanell 2007: 155).

At a more advanced stage, déjà marks ongoing events in the past,

15. Ch(ristina). C'est avec Depardieu mais je l'ai déjà vu une fois (It is with Depardieu that I have watched him once)

Benazzo examined closely the development of déjà in Spanish L1 FSL (see Table 4 below). When inflection is marked on VP, at the post-basic variety stage, déjà marks perfective aspect and past before past tense meaning (TT before Time of Utterance and Time of Situation before TT) as in 16 and 17,

16. B(ernarda): je /swi ale/ à la maison de ma sœur * $\mathrm{y}^{*}$ après je /returne/ à la maison à $8 \mathrm{~h}$...je [arrive] à la maison à $8 \mathrm{~h}^{*} \mathrm{y}^{*}$ la fête déjà fini (I went to the home of my sister and then I went back home at 8 ... I arrived at my place at $8 \mathrm{~h}$ and the party was already finished) (3.2),

17. $\mathrm{Al}$ (fonso): tu déjà [ekrive] mon numéro de telephone (you have already written down my phone number) (1.4).

Among Japanese learners at the intermediate and advanced low stage, scalar adverbs souvent (frequently) and toujours (always) are used, with occasional misplacement of the adverb, with a similar meaning as in the data analysed above,

18. Ka. Kaguya souvent pleurait. (Kaguya often cried),

19. Ayaka. Il toujours cache dans la cathédrale mais toujours parce qu'il veut sortir et voir la ville de Paris (he always hides in the cathedral but always because he wants to go out and see the town of Paris).

Time adverbs develop in the following sequence in the various sets of data analysed: Temporal adverbs of position precede the use of all other types of adverbs. While TAPs contribute mainly to 
deictic and anaphoric reference to Topic Time as from the initial stage of acquisition, scalar time adverbs such as toujours, souvent, déjà and encore convey mainly aspectual values of habituality, iteration and continuity. TAPs also act as connectives. At later stages of development in FSL, in interaction with verbal inflection scalar adverbs contribute to temporal anaphoric linkage in the past in terms of remoteness.

\subsection{Degree adverbs}

Amidst the three classes of degree adverbs identified by Abeillé, Doetjes, Molendijk and De Swart (2004: 193), FSL learners acquire degree quantifiers such as beaucoup at a very early stage, other degree adverbs such as intensity (légèrement (lightly)) or completion adverbs (partiellement (partly)) are acquired late, if at all, possibly because they are -ment adverbs. Très (very) and beaucoup (much) are confused by Japanese L1 FSL learners as in 20 and 21.

20. Ai. Aujourd'hui j'étudi français. J'étudiait français très. Je veni au France (To-day, I learn French. I learnt French much. I came to France)

21. Ai. Et je n'ai pas de memorise parce que j'étudiais beaucoup (I have no memory because I learn a lot)

\subsection{Scope particles}

Various types of adverbs exert scope as from the first stages of acquisition in learner varieties. As may be observed in Tables 4, 5 and 6, additive aussi is the most frequent of all the scope particles in the learner varieties of Spanish L1 and MA L1 learners of FSL.

Table 4. Scope particles in Spanish L1 FSL (after Benazzo 2003)

\begin{tabular}{|c|c|c|c|c|c|c|c|c|c|}
\hline & \multicolumn{3}{|c|}{ Paula } & \multicolumn{3}{|c|}{ Bernarda } & \multicolumn{3}{|c|}{ Alfonso } \\
\hline & $\begin{array}{l}\text { Pre- } \\
\text { BV }\end{array}$ & $\mathrm{BV}$ & $\begin{array}{l}\text { Post- } \\
\text { BV }\end{array}$ & $\begin{array}{l}\text { Pre- } \\
\text { BV }\end{array}$ & $\mathrm{BV}$ & $\begin{array}{l}\text { Post- } \\
\text { BV }\end{array}$ & $\begin{array}{l}\text { Pre- } \\
\text { BV }\end{array}$ & $\mathrm{BV}$ & $\begin{array}{l}\text { Post- } \\
\text { BV }\end{array}$ \\
\hline aussi & 1 & 1 & & & & & & & \\
\hline $\begin{array}{l}\text { aussi/encore } \\
\text { (additive) }\end{array}$ & & & & & 14 & 65 & & & 125 \\
\hline déjà & & 1 & & & & 10 & & & 83 \\
\hline encore & & & & & & & & & \\
\hline $\begin{array}{l}\text { encore / autre } \\
\text { fois (iterative) }\end{array}$ & & & & & 2 & 3 & & & 23 \\
\hline $\begin{array}{l}\text { encore } \\
\text { (continuative) }\end{array}$ & & & & & & 1 & & & 0 \\
\hline seulement & 3 & 31 & & 13 & 63 & 80 & & & 74 \\
\hline
\end{tabular}


Table 5. Placement of scope particles in Spanish L1 FSL (after Benazzo and Giuliano 1998)

\begin{tabular}{|l|l|l|l|l|l|l|}
\hline & \multicolumn{2}{|l|}{$\begin{array}{l}\text { Position 1 (between Topic } \\
\text { and X) }\end{array}$} & Position 2 (utterance initial) & \multicolumn{2}{l|}{ Position 3 (Post-verbal) } \\
\hline & Bernarda & Paula & Bernarda & Paula & Bernarda & Paula \\
\hline aussi & 3 & 1 & 29 & & 25 & 1 \\
\hline seulement & 9 & 2 & 48 & 21 & 9 & \\
\hline
\end{tabular}

Table 6. Placement of scope particles in MA L1 FSL (after Véronique 2012)

\begin{tabular}{|l|l|l|l|l|l|l|l|l|l|}
\hline & \multicolumn{2}{|l}{ Position 1 (between Topic and X) } & \multicolumn{2}{l}{$\begin{array}{l}\text { Position 2 (utterance } \\
\text { initial) }\end{array}$} & $\begin{array}{l}\text { Position } \\
\text { verbal }\end{array}$ \\
\hline & $\begin{array}{l}\text { Zahra } \\
(\mathrm{Z})\end{array}$ & $\begin{array}{l}\text { Abdelmalek } \\
(\mathrm{A})\end{array}$ & $\begin{array}{l}\text { Abdessamad } \\
(\mathrm{Ab})\end{array}$ & $\mathrm{Z}$ & $\mathrm{A}$ & Ab. & Z & A & Ab. \\
\hline aussi & 31 & 24 & 33 & 3 & 2 & 3 & 3 & 12 & 17 \\
\hline même & 0 & 5 & 1 & 5 & 91 & 88 & 0 & 4 & 4 \\
\hline encore & & & & 8 & 0 & 3 & 9 & 2 & 11 \\
\hline
\end{tabular}

Table 6 provides information on the use of scope particles aussi, même (even) and encore in MA FSL learners. Aussi is used by all the MA L1 informants at various stages of the development of their learner varieties, from pre-basic to post-basic stages. It is used with both contrastive focus and contrastive topics in its DA. The particle exerts both narrow and wide scope although adjacency to the element within its DA is the most frequent placement. In MA L1 FSL aussi is not used first at the periphery of the clause before working its integration in sentence internal position. Moroccan learners differ on that count from Spanish learners (see Benazzo 2005). The scope of aussi goes mainly to the left. Example 22 illustrates the use of aussi with a contrastive topic in its DA,

22. I. est-ce que tu penses que il était un peu raciste avec toi

('do you believe he was a little racist with you')

A. cent pour cent la police aussi /e/ raciste

('hundred per cent (sure) the police also is racist') (2.7)

In the Interfra data, aussi has been analysed by Sanell (2007) and Hancock and Sanell (2009). In Swedish L1 FSL, aussi is used as from the initial stage of acquisition with an additive meaning as observed also in data from the ESF project (Benazzo, 2000, 2005; Véronique 2012). Aussi tends to occupy either post topic, post verbal or final position at all stages of acquisition. The advanced learners of the Interfra project make a more frequent use of aussi in final position than the native speakers (see also Thörle 2020 for German L1 learners of FSL). 
23. I: oui . tu: \# c'est le premier livre en français que tu lis ? (Yes, is it the first book in French that you read?)

E: non ah ouais je j'ai lu « Maigret et l'Indicateur » + aussi (Pel, sta 2) (non yeah I have read « Maigret et l'Indicateur » also).

In MA L1 FSL, meme is acquired later than aussi. Meime is found with NPs, presentationals and clauses containing full finite verbs. The use of meme, with narrow or wide scope, does not seem to be determined by the presence of inflection on the verb.

24. A. avant /ja pan/ droit + meime par exemple comme les Giscard ('before there is no right + even for example during Giscard's time') ...

I. on peut manifester ('one may demonstrate')

A. oui / po/ / manifeste/ + mêne maintenant / jãn/ pas la police ('yes can demonstrate + even now there's no police') /ikõntrolel pour la carte d'identité ('it checks for your ID') (2.7).

In MA L1 FSL, encore may be used with NPs, presentationals and clauses containing full finite verbs. It conveys additive meaning (more) and it marks also iteration and continuity.

25. I. parce que tu es rentrée à l'hôpital tu as pas travaillé ?

('because you came back from hospital you did not work?')

Z. non euh /dor/ à l'hôpital euh huit jours

('no sleep at hospital eight days') ...

Z. après /sort/ à la maison + euh /dorme/ un petit peu + ('then come back to the house + sleep a little')

+ encore quinze jours + après /le parti/ maroc

('fifteen days still (to go) + then go Morocco') (Zahra (2.7a)

In the Swedish Interfra data (Sanell 2007: 133), encore is present as from the intermediate stage as in 26 with an additive meaning,

26.Ch(ristina): oui deux fois parce que/ je suis resté d'abord neuf mois, et puis neuf mois encore.

Besides, there are also some tokens of encore as a textual marker in the Interfra data, at more advanced stages of FSL acquisition (Hancock 2014).

In a nutshell, scope particles such as aussi, encore, déjà, même etc. are found among all the learner varieties examined. These particles convey nearly similar temporal and textual values in the different learner varieties. It should be noted that aussi is more frequently used in learner varieties than in native speaker data (Hancock \& Sanell 2009).

\section{3. - ment adverbs}

Hancock and Sanell (2009) quoting Bilger's (2004) analysis of French -ment adverbs claim that vraiment is by far the most frequent adverb in spoken French. One the first -ment adverbs present in 
Spanish LI learners of the ESF project is seulement (solamã) (only), see examples 27 and 28 below. This use seems typical of Spanish L1 learners although it may be also observed with the same restrictive meaning in Interfra data. Moroccan L1 learners convey the same restrictive meaning through the use of même.

27. I. Tu connaissais le film? (...) Tu le connaissais avant? (Did you know the film? Did you know it before?

B. *al actor*/solamã/ (Only the actor) (1.5)

28. I. Vous aviez beaucoup de roses? (You had many roses?)

B. seulement [Ze me] * preocupe* seulement de toutes les roses (3.1) (only I cared for all the roses only

Seulement is quite rare in Interfra data (Hancock \& Sanell 13-14) although it is attested quite early, as from the post-initial stage of acquisition,

29. I. vous parlez anglaise? (you speak English)

$\mathrm{P}(\mathrm{elle})$. yeah seulement anglaise (Yes only English).

30. I: mm / est-ce que tu a:s / séjourné en France donc est-ce que tu as travaillé ou ... ? (Have you spent some time in France then have you worked or...?

E: non j'ai seulement étudié vingt-cinq heures par semaine (No I have only studied twenty-five hours per week) (Yvonne)

In the Interfra data, besides seulement, the most frequent -ment adverb is vraiment. As from stage 2 in the Bartning and Schlyter scale of development, the first token of vraiment is holophrastic. Later, vraiment is integrated to the utterance in post-verbal position.

-ment adverbs are found in the data of advanced low Japanese L1 FSL learners. These adverbs are either time adverbs as in 31 and 32,

31. Ka. Finalement, elle rentre à la lune (finally, she goes to the moon),

32. Ayaka. Et soudainement le cerf a commence à courir (and suddenly the stag starts to run),

or manner adverbs,

33. Ayaka. et toujours on skie normalement (and always we ski normally),

34. Ayaka. mais malheureusement elle oubliait son nom (but unfortunately she forgot her name),

or degree adverbs,

35. Ayaka. Une ceinture exactement pareille (a belt exactly similar) 
or speech act adverbs,

36. Ami. évidemment il n'a pas d'amis (clearly he has no friends).

-ment adverbs are acquired late as from the advanced low stage of FSL acquisition. The only exception is the use of seulement in Spanish L1 learners which offers a clear case of interference from L1.

\subsection{Summary}

Learners with different L1 backgrounds exhibit some degree of variation in the use of the adverbs investigated. Sanell (2007: 154), for instance, shows that the first tokens of encore in learner varieties (L1 Swedish) at intermediate stage bear aspectual "continuative" meaning whereas the first tokens of encore in L1 Spanish learners of the ESF project bear "iterative meaning". Sun (2012: 123) emphasizes the fact that her Chinese L1 learners made little use of the diversity of time adverbs available in French, using aussi extensively. French learners with a Romance language background use items like Fr. seulement extensively.

\section{Discussion}

Given the heterogeneous lexical nature of this class of words, various types of adverbs are present as from the early stages of L2 acquisition. Early acquisition of adverbs is probably due to the salience of this class of items (Ellis 2008). Given that adverbs pertain to various semantic classes, they are more liable to L1 or L2 transfer than strict grammatical functors; the use of Fr. seulement provides a good case in point. In the course of the acquisition of FSL, adverbs are placed in various positions in finite or non-finite utterances, exerting wide or narrow scope in their domain of application. The type of scope exerted and the placement of adverbs vis à vis the constituents in their DA as illustrated for instance by aussi, exhibit some variation according to the groups of learners involved. This may be attributed to L1 transfer. It must be added that various groups of FSL learners tend also to overuse aussi as compared to native speakers (Sun 2014, Thörle 2020).

As from the first stages of acquisition, adverbs are placed in the three key positions identified by Bernini (2014) in early learner varieties. In French L1, these positions are frequently occupied by adverbs as adjuncts.

As a syntactic word class, adverbs in FSL do not exhibit the same properties as in French L1. The constraints on the alignment of integrated adverbs described by Bonami et al. (2004: 158) rarely apply in FSL except for encore un peu (a little again) for instance, in the Interfra data because the alignment of adverbs is a rare phenomenon in FSL.

The attempts of Benazzo (2004) and Hancock and Sannell (2009) to sketch an order of acquisition of a set of adverbs in their data bases according to the stage of proficiency reached are challenging. From the data investigated in section 7 , some regularities are observed: i) temporal adverbs of position, connectives and degree quantifiers are the first type of adverbs to be used together with additive aussi; ii) temporal adverbs of frequency, of contrast and of duration are used later with different semantic values according to the L1 and L2 of the learners; -ment adverbs tend to be acquired late 
except for specific cases of L1 transfer as for seulement in the Spanish L1 FSL learner varieties. Certain semantic classes of adverbs, mainly marked by -ment adverbs, such as speech act adverbs are rarely found in FSL learner varieties. The acquisition of adverbs in FSL is gradual and orderly but transfer from L1 interferes with a common acquisitional sequence for all groups of learners. 


\section{References}

Andersen, Roger W., 1984, The one to one principle of Interlanguage construction, Language Learning, 34: 77-95. https://doi.org/10.1111/j.1467-1770.1984.tb00353.x

Abeillé, Anne, Doetjes, Jenny, Molendjik, Arie, de Swart, Henriëtte, 2004, Adverbs and quantification, in Corblin, Francis, de Swart, Henriëtte (eds.), Handbook of French semantics, pp. 185-209, Stanford: CSLI Publications.

Bartning, Inge, 2009, The advanced learner: ten years later. In E. Labeau \& F. Myles (Eds.), The advanced learner variety: the case of French, 11-40. Oxford, Berlin, New-York: Peter Lang.

Bartning, Inge, Schlyter, Susanne, 2004, Itinéraires acquisitionnels et stades de développement en français L2, Journal of French language Studies, 14, 281-299 DOI:10.1017/S0959269504001802.

Benazzo, Sandra, Giuliano, Patrizia, 1998, Marqueurs de négation et particules de portée en français L2: où les placer? Acquisition et Interaction en Langue Etrangère 11, 35-61.

Benazzo, Sandra, 2003. The interaction between the development of verb morphology and the acquisition of temporal adverbs of contrast. A longitudinal study in French, English and German L2. In Dimroth, Christine \& Starren, Marianne (eds.), Information structure and the dynamics of language acquisition, 187-210. Amsterdam: John Benjamins.

Benazzo, Sandra, 2005. Le développement des lectes d'apprenants et l'acquisition de la portée à distance en L2. Acquisition et Interaction en Langue Etrangère 23, 65-93.

Benazzo, Sandra, 2012, Structure informationnelle et organisation du discours dans l'acquisition des langues seconds. Dossier d'HDR, vol. 2, Paris 8.

Bernini, Guiliano, 2014, Lexical categories in the target language and the lexical categorisation of learners: the word class of adverbs, in Watorek Marzena, Benazzo Sandra, Hickmann Maya (eds). Comparative Perspectives on Language Acquisition. A tribute to Clive Perdue, pp. 92- 107, Bristol: Multilingual Matters

Bilger, Mireille, 2004. Quelques données sur les adverbes en ment dans le corpus de référence de français parlé. Recherches sur le français parlé, 18: 63-82.

Bonami, Olivier, Godard, Danièle, Kampers-Manhe, Brigitte, 2004, Adverb classification, in Corblin, Francis, de Swart, Henriëtte (eds.), Handbook of French semantics, pp. 143-184, Stanford: CSLI Publications.

Chanet, Catherine, 2004. Fréquence des marqueurs discursifs en français parlé: quelques problèmes de méthodologie . Recherches sur le français parlé 18: 83-106.

Cinque, Guielmo., 1999, Adverbs and functional heads. A cross-linguistic perspective, Oxford: OUP

Creissels, Denis, 2006, Syntaxe Générale, une introduction Générale 1. Catégories et constructions, Paris, Hermès-Lavoisier.

Dimroth, Christine, Starren, Marianne, 2003, Information structure and the dynamics of language acquisition. Amsterdam: John Benjamins.

Dimroth, Christine, Watorek, Marzena, 2000, The scope of additive particles in basic learner languages, Studies in Second Language Acquisition 22, 307-336. 
Dimroth, Christine, 2018. Beyond Statistical Learning: Communication Principles and Language Internal Factors Shape Grammar in Child and Adult Beginners Learning Polish through Controlled Exposure Language Learning 68: 4: 863-905, DOI: 10.1111/lang.12294.

Ellis Nick, 2008. The dynamics of Second language emergence: Cycles of language use, language change and language acquisition. The Modern language Journal, 92: 2: 232-249.

Giacomi Alain, Stoffel Henriette, Véronique Daniel (éds.) (2000) Appropriation du français par des Marocains arabophones à Marseille, Aix-en-Provence: Publications de l'Université de Provence.

Giuliano Patrizia, Véronique Daniel, 2005, The acquisition of negation in French L2. An analysis of Moroccan Arabic and Spanish «learner varieties ». In: Henriëtte Hendricks (ed.). The structure of learner varieties, pp. 355-403, Berlin, Mouton De Gruyter.

Guimier, Claude,1993, L'établissement d'un corpus de circonstants, in Guimier, Claude (éd.), 1001 circonstants, pp. 11-46, Caen: Presses universitaires de Caen

Guimier, Claude, 1996, Les adverbs du français : le cas des adverbs en -ment, Paris: Ophrys.

Hancock, Victorine, 2014, Pragmatic use of temporal adverbs in L1 and L2 French. Functions and syntactic positions of textual markers in a spoken corpus. In Lindqvist, Christina, Bardel, Camilla (eds.), The acquisition of French as a second language, pp. 29-51, Amsterdam:John Benjamins.

Hancock, Victorine \& Sanell, Anna, 2009, The acquisition of four adverbs in a learner corpus of L2

French, Discours. Revue de linguistique, psycholinguistique et informatique, 5, http://discours.revues.org/7368. DOI : 10.4000/discours.7368

Hendriks, Henrëtte ed., 2005, The structure of learner varieties. Berlin: Mouton de Gruyter.

Hengeveld, Kees (no date), Adverbs

Kerrou, Nadine, 2019, Expression de la temporalité dans le discours d'apprenants japonais du français : une approche acquisitionnelle et didactique, Thèse de doctorat, Université de Lille.

Klein, Wolfgang, 1986, Second language acquisition, Cambridge, C.U.P.

Klein, Wolfgang, 1994, Time in Language, London: Routledge.

Klein, Wolfgang, 2008, The topic situation. In B. Ahrenholz, U. Bredel, W. Klein, M. Rost-Roth, \& R. Skiba (Eds.), Empirische Forschung und Theoriebildung: Beiträge aus Soziolinguistik, Gesprochene-Spracheund Zweitspracherwerbsforschung: Festschrift für Norbert Dittmar, 287-305, Frankfurt am Main: Peter Lang.

Klein, Wolfgang, Perdue, Clive, 1992, Utterance structure (Developing grammars again), Cambridge. Cambridge University Press.

Klein, Wolfgang, Perdue, Clive 1997. The Basic Variety (or Couldn't natural languages be much simpler?). Second Language Research 13, 301-347.

König, Ekeehard, 1991,. The meaning of focus particles. A comparative perspective. London: Routledge. Klingler, Dominique, 1999, Connecteurs en français (L2) et «équivalents » en japonais (L1): une perspective sur la production bilingue, Thèse de doctorat, Paris III-Sorbonne nouvelle.

Perdue, C. (1984). Second language acquisition by adult immigrants: a field manual. Rowley, MA: Newbury House.

Nølke, Henning, 1993, Le regard du locuteur. Pour une linguistique des traces énonciatives, Paris: Éditions Kimé.

Perdue, Clive (ed) 1993. Adult Language Acquisition: Cross-Linguistic Perspectives. Volume 1 Field Methods, Volume 2. The Results, Cambridge. Cambridge University Press. 
Perdue, C. (1996). Pre-basic varieties: the first stages of second language acquisition. Toegepaste Taalwetenschap in Artikelen 55, 135-150.

Prévost, Philippe, White, Lydia, 2000, Missing surface inflection or impairment i Second Language Acquisition? Evidence from tense and agreement. Second Language Research 16 (2), 103-33.

Renoud Loïc, 2016, Vers une approche par concepts pour l'apprentissage des temps du passé en français langue étrangère dans le contexte de l'université au Japon, Thèse de doctorat, Université Lyon 2.

Sanell, Anna, 2007, . Parcours acquisitionnel de la negation et de quelques particules de portée en français L2, Doctoral Thesis, Stockholm University.

Schlyter, Suzanne, 2005, Adverbs and Functional Categories in L1 and L2 Acquisition. In J.M. Dewaele (ed.). Focus on French as a Foreign Languages. Multidisciplinary approaches, 36-62, Clevedon: Multilingual Matters.

Starren, M. (2001). The second time. The acquisition of temporality in Dutch and French as a second language. Utrecht: LOT.

Starren, Marianne, Van Hout, Roland, 1996, Temporality in learner discourse: what temporal adverbs can and what they cannot express. Zeitschhrift für Litteraturwissenschaft und Linguistik, 104, 35-50.

Sun, Jili, 2014, Is it necessary for Chinese Mandarin Speakers to mark time? Reflections about the use of temporal adverbs with respect to verbal morphology, in Watorek Marzena, Benazzo Sandra, Hickmann Maya (eds). Comparative Perspectives on Language Acquisition. A tribute to Clive Perdue, pp. 108-132, Bristol: Multilingual Matters.

Thörle, Britta, 2020, "Et le chien aussi i' regarde". Particule additive aussi et structure informationnelle en français L2, Language, Interaction, Acquisition, 11: 2: 298-324.

Véronique Georges Daniel, 2014, The acquisition of additive scope particles by Moroccan Arabic L1 learners of French, in Lindqvist, Christina, Bardel, Camilla (eds.), The acquisition of French as a second language, pp. 119-41, Amsterdam: John Benjamins.

Versteegh Kees, 2018, Temporal adverbs of contrast in the Basic Variety of Arabic, in Manfredi, Stefano, Tosco, Mauro (eds.), Arabic in contact, pp. 233-250, Amsterdam: John Benjamins.

Watorek, M. \& Perdue, C. (1999). Additive particles and focus: observations from learner and speaker discourse. In H. Hendriks (Ed.), The structure of learner varieties, 445-488. Berlin,

Watorek, M. \& Dimroth, C. (2004). Additive scope particles in advanced learner and native speaker discourse, in Hendriks, Henriëtte (ed.), The structure of learner varieties, pp. 445-488, Berlin: Mouton De Gruyter.

Watorek, Marzena, 2010, De l'étude de l'acquisition des langues secondes aux descriptions linguistiques : aussi et encore en français, Langue française, 168, p. 107-125. 